\title{
Perceived Service Quality Attributes in Public Transport: Inferences from Complaints and Negative Critical Incidents
}

\author{
Margareta Friman \\ Bo Edvardsson \\ University of Karlstad, Sweden \\ Tommy Gärling \\ Göteborg University, Sweden
}

$\overline{\text { Abstract }}$

A sample of 200 complaints filed to a public transport company and 210 negative critical incidents (NCIs) obtained from on-board interviews were analyzed with the purpose of inferring perceived service quality (PSQ) attributes of public transport. The most frequent complaints and NCIs concerned employee behavior and punctuality, followed by missing or inaccurate information and inadequate planning. In a follow-up mail survey, a representative sample of 997 respondents reported if they remembered having experienced prototypical NCIs constructed on the basis of the complaints. Confirming the validity of the inferred PSQ attributes, all NCIs were reported to have been experienced by at least some respondents. NCIs related to employee behavior were, however; less frequently remembered, whereas those related to vehicle design and space, punctuality, and traffic planning were more frequently re- 
membered. Taken together, the results suggest that PSQ attributes in public transport refer to employee behavior, reliability, and simplicity. Finally, inferences made from customer complaints and negative critical incidents are shown to extend our knowledge of perceived service quality attributes in public transport.

\section{Introduction}

The problem currently facing public transport operators is that although travel demand steadily increases, the demand for public transport declines (Benister 1992) due to increased automobile use. Andreassen (1995) feels that transport operators often make the mistake of mass marketing a standard service to a heterogeneous market. Changing the marketing strategy in a desirable direction requires a focus on how customers' perceptions are related to characteristics of the service. However, research on public transport has tended to emphasize the technical aspects of the service (e.g., vehicle and facility design), leaving out psychological and social aspects that may be more important (Everett and Watson 1987). It has, therefore, been argued that transportation systems need to be considered from a behavioral perspective rather than from an exclusively technological view (Hartgen 1981). Knowledge of perceived quality of public transport services may be essential if the service is to become more attractive to consumers who have other alternatives (e.g., automobile). Such knowledge gained from behavioral service-quality research will guide the formulation of strategies that can influence customers' travel choices and satisfaction.

The focus of this article is perceived service quality of public transport services (i.e., buses and streetcars). Specifically, the aim is to empirically examine whether previous findings concerning perceived service quality (PSQ) attributes generalize to public transport services. More than 30 studies during the last 10 years of customer PSQ were examined in a recent review (Edvardsson 1996) showing that how the employees treat the customers, reliability of the service, simplicity (e.g., clearness and accessibility of information), and recovery when something goes wrong are significant factors. The hypothesis of this 
study is that these factors are also important in public transport, although it is realized that there may be differences between different types of services (Lovelock 1983).

A public transport service may be characterized by means of objective attributes or performance measures (e.g., travel time, cost, and frequency of service). A distinction can also be made between episodes, critical incidents, and PSQ (see Figure 1). An episode refers to a trip or part of a trip, such as walking to a bus stop or buying a ticket. The customer may evaluate any such episode as positive or negative when it differs from a norm or expectation (Strandvik 1994). Such episodes, which may be either positive or negative, are labeled critical incidents (Flanagan 1954). It may be assumed that PSQ, to some extent, depends on the number of positive or negative critical incidents which are remembered

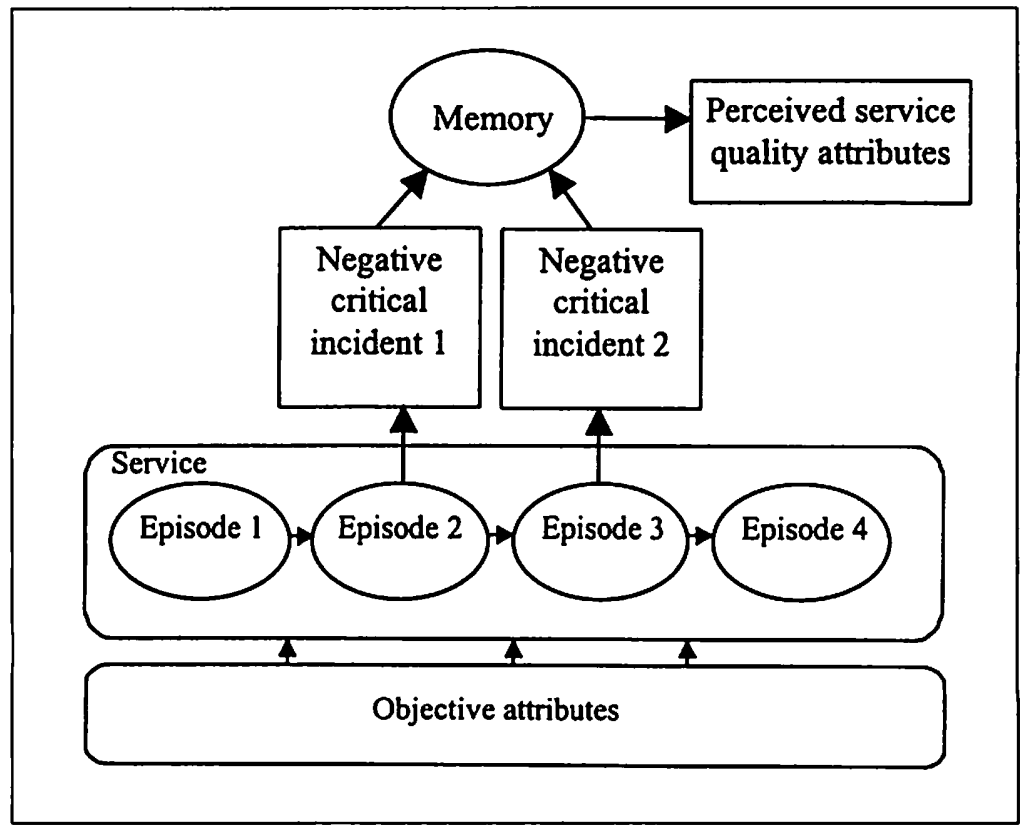

Figure 1. Hypothetical relationships between objective attributes of public transport services, episodes, and negative critical incidents encountered by consumers, and perceived service quality attributes. 
(e.g., Folkes 1994; Johns and Tyas 1997). In the case of public transport services, negative critical incidents (NCIs) may have more impact, since, in contrast to some other services (e.g., restaurants, entertainment), avoiding dissatisfaction may be more important that attaining satisfaction. An example is that delays lead to perceiving the service as unreliable. However, a bus or streetcar that is on time may go unnoticed. Another example is that remembering episodes when staff is not helpful may cause the impression of non-professional staff, whereas the reverse has no influence. Of course, in neither example are the perceptions necessarily correct. Still, if many NCIs are investigated, inferences may be possible to make about how service quality is perceived.

The assumption that PSQ attributes depend on negative critical incidents makes it appropriate to use the critical incident technique (CIT) for obtaining information about perceived service quality attributes. CIT refers to " . . a procedure for gathering certain important facts concerning behavior in defined situations ..." (Flanagan 1954: 335). Some criteria have been stated for defining a critical incident (e.g., Flanagan 1954; Youngdahl and Kellogg 1996). For instance, it has been suggested that a critical incident should involve specific actions and be extremely unsatisfactory or satisfactory. The description must also provide sufficient details. Studies of critical incidents in service research have been conducted focusing either on customers' or employees' perceptions. For instance, Bitner, Booms, and Ttreault (1990) reported the results of several studies of service quality in airlines, hotels, and restaurants were the CIT was used. Both satisfactory and dissatisfactory specific events and behaviors were included. The technique has also been used to analyze only negative critical incidents in, for example, high technology services (Edvardsson 1988), banks (Olsen 1992), and automobile services (Stauss 1992).

Information about critical incidents may be obtained in different ways. In early CIT.studies, it was common to ask experts to describe critical incidents they had experienced. As the popularity of CIT increased (Stauss 1993), a variety of methods of eliciting critical incidents were employed, including, for instance, personal interviews, focus group interviews, and questionnaires. An un- 
obtrusive method of obtaining NCIs may be to use archival customer-complaint data. Cadotte and Turgeon (1988), who analyzed the content of complaints as well as compliments, found that in general complaints contain extremely unsatisfactory experiences. Thus, it seems reasonable to assume that complaints are similar to NCIs. In the first study reported here, access was given to a database compiled by a public transport company. A sample of the filed complaints was categorized and counted.

Only a small number of customers complain when they have had a negative experience with a service (Day et al. 1981) (see note 4). Those who do may furthermore differ importantly from other customers. To guard against such potential reporting biases, in the second study a sample of customers was asked to report NCIs in face-to-face interviews.

The aim of the CIT is to obtain a detailed, comprehensive description of the critical incidents as they are experienced (Olsen 1992). In order to extract meaningful information from such descriptions, they must be categorized. Categorization of critical incidents consists of (1) developing knowledge of the area to be investigated, (2) developing guiding principles for distinguishing critical from other incidents, (3) developing categories as well as rules defining inclusion, and (4) actually categorizing the incidents. Depending on aim and purpose, categorization can either be inductive or deductive. In any case, the categorization may be unreliable. However, Andersson and Nilsson (1964), who tested whether groups of students would categorize incidents differently than the researcher, showed that, even if the students placed a critical incident in a different category at the lowest level, agreement was usually satisfactory at superordinate levels. Together, the methodological studies reported by Andersson and Nilsson (1964) and others (e.g., Ronan and Latham 1974) suggest that categorization may, in fact, be satisfactorily reliable. Still, it is advisable to include checks of reliability in any single study.

The aim of the third study was partly to validate the categories in the preceding studies and partly to assess the frequency of negative critical incidents in a representative sample. On the basis of the complaints, a set of prototypical 
descriptions of NCIs was prepared. In a mail questionnaire, these descriptions were presented to respondents who indicated for each whether or not they remembered having experienced a similar event.

The present research thus aims at examining the hyposthesis, based on previous findings in different service industries (Edvardsson 1996), that the following are important PSQ attributes in public transport: employee behavior, reliability, simplicity, and recovery. If PSQ attributes are related to negative critical incidents, it is appropriate to use the CIT. Descriptions of NCIs may be obtained from complaints, interviews, or survey questionnaires. All these techniques were used in different studies to combine their relative strengths and weaknesses. The following three sections present the results. In the last section, the main findings are summarized and discussed.

\section{Complaints}

\section{Data Set}

The public transport company in Gothenburg, Sweden invites customers to make complaints by phone, postcard, letter, or fax. Two hundred' such complaints were collected from their database, consisting of approximately 3,000 complaints obtained during the last 12 months (an average of approximately 250 complaints each month). A few complaints were screened since they were not possible to read or did not include sufficient information. Of the remaining complaints in the database, 15 to 17 were randomly chosen from each month.

\section{Analyses and Results}

The selected complaints were categorized independently by two judges according to an inductive procedure where the categories were developed on the basis of the descriptions. After reading all complaints, the descriptions were grouped by the judges in categories based on similarity. The grouping was changed and refined until the descriptions in a category were more similar to each other than to descriptions in any other category. Agreement between the judges was almost complete; the disagreements were resolved by discussion. 


\section{Table 1}

\section{Frequencies of Categorization of Incidents Obtained from Complaints}

\begin{tabular}{|c|c|c|c|}
\hline Superordinate Group & Main Category & Freque & \\
\hline \multirow[t]{4}{*}{ Treatment and Action } & Uncomfortable driving & 47 & \\
\hline & Unsafe driving & 17 & \\
\hline & Driver failed to stop & 15 & \\
\hline & Bad treatment by other employee & 5 & $(\Sigma 84)$ \\
\hline \multirow[t]{3}{*}{ Punctuality } & Early departure & 15 & \\
\hline & Late departure & 15 & \\
\hline & Canceled trip without notice & 11 & $(\Sigma 41)$ \\
\hline \multirow[t]{3}{*}{ Information } & $\begin{array}{l}\text { Arrival and departure times } \\
\text { (including delays) }\end{array}$ & 21 & \\
\hline & Destination & 6 & \\
\hline & Tickets and their validity & 5 & $(\Sigma 32)$ \\
\hline \multirow[t]{2}{*}{ Technical Malfunctioning } & Vehicle & 1 & \\
\hline & Equipment & 8 & $(\Sigma 9)$ \\
\hline \multirow[t]{3}{*}{ Vehicle Design and Space } & Crowding & 5 & \\
\hline & Discomfort & 5 & \\
\hline & Embarking and disembarking & 2 & $(\Sigma 12)$ \\
\hline \multirow[t]{2}{*}{ Traffic Planning } & Fare structure & 9 & \\
\hline & Scheduling & 5 & $(\Sigma 14)$ \\
\hline \multirow[t]{3}{*}{ Other. } & Retailer & 2 & \\
\hline & Injury & 1 & \\
\hline & Bus stop & 5 & $(\Sigma 8)$ \\
\hline
\end{tabular}

Table 1 displays the frequencies in each category. Common features formed the basis for labeling them. As can be seen, the categories fall into a number of superordinate groups. By far, most complaints referred to how customers are treated by staff and whether or not staff takes appropriate actions (Treatment and 
Action). Examples include unsafe and uncomfortable driving. Some complaints in this group also pertain to interaction with other staff.

The second most frequent category, Punctuality, mainly referred to complaints about early or late departures. A few were complaints about trips canceled without notice.

Almost equally frequent were complaints about inaccurate or missing information (Information) about arrival or departure times and destinations. In addition, complaints were filed about confusing ticket information. Such information is provided by the driver or other staff on request but is also available in timetables. The information appeared to be particularly confusing concerning traffic changes.

Three remaining groups, together accounting for 17 percent of the complaints, referred to malfunctioning of loudspeakers or reading lights (Technical Malfunctioning); crowding, discomfort, or difficulties in embarking and disembarking the vehicle (in particular, by handicapped or parents with baby carriages) (Vehicle Design and Space); and fare structure and scheduling (Traffic Planning).

A last category (Other) included complaints that could not be classified to the other categories. Two concerned dissatisfaction with retailers (in Sweden, tickets are frequently sold in drugstores). Injuries during travel were reported on one occasion. More frequently, complaints were filed about lack of protection against weather conditions at bus stops, either due to design features or limited open hours.

\section{On-Board Interviews}

\section{Procedure}

During a week at randomly selected times of the day, two trained interviewers approached adult customers of both genders traveling on buses and street cars in Gothenburg. Ninety agreed to be interviewed, which was close to a 100 percent response rate. They were asked to attempt to remember an episode in their contacts with the public transport company during the past year that they 
perceived as negative or unpleasant. Respondents were then asked to describe the episode in as much detail as possible. Each was encouraged to report three such episodes, but a majority reported only one or two. Only a few respondents reported incomplete or inappropriate information. Altogether 210 usable NCIs were reported.

\section{Results}

Again, two judges ${ }^{2}$ independently categorized the descriptions of the $\mathrm{NCIs}$ following the procedure for complaints. As can be seen in Table 2, the results are similar to complaints (Table 1). The categories differ slightly, although it is possible to form the same superordinate groups. New NCIs include traffic accident, bus running out of fuel, and traveler vomiting. Also, Treatment and Action and Punctuality are the most frequent superordinate groups, although the order is reversed, in that more NCIs were classified in the second rather than in the first category. Furthermore, Traffic Planning is a more frequent category.

\section{Mail Survey}

\section{Procedure}

A set of descriptions to be included in a questionnaire was selected on the basis of the complaint data. Prototypical exemplars were construed corresponding to the superordinate groups described in Table 1. Eighteen descriptions were selected and modified in several pretests in which different student samples were recruited. The descriptions, which were included in the survey questionnaire, are given in the Appendix. As can be seen, some of the main categories were represented by several descriptions, whereas others were only represented by a single description.

In the questionnaire, the descriptions were presented side by side, two on each page. Instructions explained that the descriptions referred to episodes that had occurred to passengers of buses or streetcars in the area where the respondents were living. Respondents were asked to read each description and to answer a number of questions. ${ }^{3}$ These included whether respondents had never, a few times, occasionally, or regularly experienced a similar incident; whether they 
Table 2

Frequencies of Categorization of Incidents Obtained from On-Board Interviews

\begin{tabular}{|c|c|c|c|}
\hline Subordinate Group & Main Category & Freque & \\
\hline \multirow[t]{4}{*}{ Treatment and Action } & Uncomfortable driving & 21 & \\
\hline & Unsafe driving & 11 & \\
\hline & Driver failed to stop & 15 & \\
\hline & Bad treatment by other employee & 3 & $(\Sigma 50)$ \\
\hline \multirow[t]{3}{*}{ Punctuality } & Early departure & 45 & \\
\hline & Late departure & 5 & \\
\hline & Canceled trip without notice & 14 & $(\Sigma 64)$ \\
\hline \multirow[t]{3}{*}{ Information } & $\begin{array}{l}\text { Arrival and departure times } \\
\text { (including delays) }\end{array}$ & 17 & \\
\hline & Destination & 1 & \\
\hline & Tickets and their validity & 3 & $(\Sigma 21)$ \\
\hline \multirow[t]{2}{*}{ Technical Malfunctioning } & Vehicle & 7 & \\
\hline & Equipment & 16 & $(\Sigma 23)$ \\
\hline \multirow[t]{3}{*}{ Vehicle Design and Space } & Crowding & 2 & \\
\hline & Discomfort & 12 & \\
\hline & Embarking and disembarking & 3 & $(\Sigma 17)$ \\
\hline \multirow[t]{2}{*}{ Traffic Planning } & Fare structure & 14 & \\
\hline & Scheduling & 16 & $(\Sigma 30)$ \\
\hline \multirow[t]{4}{*}{ Other } & Traffic accident & 2 & \\
\hline & Traveler thrown off the bus & 1 & \\
\hline & Traveler vomiting & 1 & \\
\hline & Bus out of fuel & 1 & $(\Sigma 5)$ \\
\hline
\end{tabular}

did not remember when it occurred or if it was last week, last month, some time last year, or earlier; how negatively they perceived the incident; and the number of people they had told about it. In addition, respondents were asked if they had 
ever heard about someone else who had encountered a similar incident, a few times, now and then, or frequently. They also rated how negative it was.

\section{Sample}

A random sample of 2,000 respondents was selected consisting of people between 16 and 75 years of age living in Gothenburg (population approximately 450,000 ). Questionnaires were mailed to each respondent's home address with a reply-paid envelope. To increase the response rate, respondents were told that the first 100 respondents would receive a lottery ticket. Two reminders were sent out, the last one with a new copy of the questionnaire.

After three months, 997 usable questionnaires had been received corresponding to a response rate of 49.9 percent. The respondents consisted of 452 men and 545 women, which was slightly more women than living in the area $\left(\mathrm{x}^{2}\right.$ $=5.36, \mathrm{p}<0.05)$. The mean age was 41.6 years old $(\mathrm{SD}=16.2$ years). When compared to the age distribution of people in the area, the ages of 45 to 64 were under-represented, whereas the ages of 25 to 44 were over-represented $\left(x^{2}=\right.$ $24.49, \mathrm{p}<0.01)$. A university degree was held by 31 percent; 60 percent were married or cohabitating; 39 percent had one or more children younger than 18 years old living with them; and 42 percent were employed full-time and 9 percent part- time. Mean family annual income varied between SEK 201,000 and 300,000 ( 1 SEK is approximately equal to $0.15 \mathrm{USD}$ ). Fifty-one percent reported that they used public transport on average more than once a week. ${ }^{4}$

\section{Results}

Table 3 displays the number of respondents who indicated that they had experienced NCIs, mean-rated frequency of experience, and mean-rated degree of negative impact. On average, the NCIs occurred sometime during the last year ( $M=1.0$ on a 0.3 scale). Furthermore, almost all NCIs were experienced, on average, as fairly negative $(M=2.1$ on a $0-3$ scale).

Speaking to the validity of the categories developed in the preceding studies, all NCIs were reported to have been experienced by at least some respondents. However, the correspondence regarding the frequencies was not complete. Assuming that the average reported frequency of incidents in each superordinate 


\section{Table 3}

\section{Recognition Scores Mean Ratings and Standard Deviation in the Mail-Survey Questionnaire}

\begin{tabular}{|c|c|c|c|c|c|}
\hline $\begin{array}{l}\text { Superordinate } \\
\text { Group }\end{array}$ & $\underset{\text { Mategory }}{\text { Main }}$ & Question & Recognition & $M$ & $S D$ \\
\hline \multirow[t]{6}{*}{$\begin{array}{l}\text { Treatment } \\
\text { and Action }\end{array}$} & $\begin{array}{l}\text { Driver refused } \\
\text { to listen }\end{array}$ & $\begin{array}{l}\text { Frequency } \\
\text { Recency } \\
\text { Impact }\end{array}$ & $44(4 \%)$ & $\begin{array}{l}0.1 \\
0.8 \\
2.6\end{array}$ & $\begin{array}{l}0.3 \\
1.0 \\
0.8\end{array}$ \\
\hline & $\begin{array}{l}\text { Not permitted to } \\
\text { enter the vehicle }\end{array}$ & $\begin{array}{l}\text { Frequency } \\
\text { Recency } \\
\text { Impact }\end{array}$ & $676(68 \%)$ & $\begin{array}{l}1.1 \\
1.1 \\
2.6\end{array}$ & $\begin{array}{l}0.9 \\
1.0 \\
0.7\end{array}$ \\
\hline & Careless driving & $\begin{array}{l}\text { Frequency } \\
\text { Recency } \\
\text { Impact }\end{array}$ & $592(59 \%)$ & $\begin{array}{l}0.8 \\
0.8 \\
1.8\end{array}$ & $\begin{array}{l}0.8 \\
0.9 \\
0.9\end{array}$ \\
\hline & $\begin{array}{l}\text { Not permitted to } \\
\text { get off the vehicle }\end{array}$ & $\begin{array}{l}\text { Frequency } \\
\text { Recency } \\
\text { Impact }\end{array}$ & $343(34 \%)$ & $\begin{array}{l}0.4 \\
0.6 \\
2.5\end{array}$ & $\begin{array}{l}0.6 \\
0.9 \\
0.7\end{array}$ \\
\hline & $\begin{array}{l}\text { Driver did not stop } \\
\text { at the bus stop }\end{array}$ & $\begin{array}{l}\text { Frequency } \\
\text { Recency } \\
\text { Impact }\end{array}$ & $329(33 \%)$ & $\begin{array}{l}0.4 \\
0.6 \\
2.6\end{array}$ & $\begin{array}{l}0.6 \\
0.8 \\
0.7\end{array}$ \\
\hline & $\begin{array}{l}\text { Bad treatment } \\
\text { by other employee }\end{array}$ & $\begin{array}{l}\text { Frequency } \\
\text { Recency } \\
\text { Impact }\end{array}$ & $212(21 \%)$ & $\begin{array}{l}0.3 \\
0.8 \\
2.1\end{array}$ & $\begin{array}{l}0.7 \\
0.9 \\
0.9\end{array}$ \\
\hline \multirow[t]{3}{*}{ Punctuality } & Early departure & $\begin{array}{l}\text { Frequency } \\
\text { Recency } \\
\text { Impact }\end{array}$ & $613(61 \%)$ & $\begin{array}{l}0.9 \\
1.0 \\
2.3\end{array}$ & $\begin{array}{l}0.8 \\
1.0 \\
0.8\end{array}$ \\
\hline & Late departure & $\begin{array}{l}\text { Frequency } \\
\text { Recency } \\
\text { Impact }\end{array}$ & $909(91 \%)$ & $\begin{array}{l}1.7 \\
1.5 \\
1.6\end{array}$ & $\begin{array}{l}0.8 \\
1.1 \\
0.9\end{array}$ \\
\hline & $\begin{array}{l}\text { Canceled trip } \\
\text { without notice }\end{array}$ & $\begin{array}{l}\text { Frequency } \\
\text { Recency } \\
\text { Impact }\end{array}$ & $560(56 \%)$ & $\begin{array}{l}0.7 \\
0.7 \\
2.3\end{array}$ & $\begin{array}{l}0.7 \\
0.8 \\
0.8\end{array}$ \\
\hline Information & $\begin{array}{l}\text { Delayed departure } \\
\text { time }\end{array}$ & $\begin{array}{l}\text { Frequency } \\
\text { Recency } \\
\text { Impact }\end{array}$ & $742(74 \%)$ & $\begin{array}{l}1.1 \\
1.0 \\
1.9\end{array}$ & $\begin{array}{l}0.8 \\
1.0 \\
1.9\end{array}$ \\
\hline
\end{tabular}


Table 3 (cont)

\begin{tabular}{|c|c|c|c|c|c|}
\hline $\begin{array}{l}\text { Superordinate } \\
\text { Group }\end{array}$ & $\begin{array}{c}\text { Main } \\
\text { Category }\end{array}$ & Question & Recognition & $M$ & $S D$ \\
\hline & Incorrect display & $\begin{array}{l}\text { Frequency } \\
\text { Recency } \\
\text { Impact }\end{array}$ & $247(25 \%)$ & $\begin{array}{l}0.3 \\
0.6 \\
2.3\end{array}$ & $\begin{array}{l}0.5 \\
0.8 \\
0.9\end{array}$ \\
\hline & $\begin{array}{l}\text { Tickets and their } \\
\text { validity }\end{array}$ & $\begin{array}{l}\text { Frequency } \\
\text { Recency } \\
\text { Impact }\end{array}$ & $64(6 \%)$ & $\begin{array}{l}0.1 \\
0.7 \\
2.3\end{array}$ & $\begin{array}{l}0.3 \\
1.0 \\
0.9\end{array}$ \\
\hline $\begin{array}{l}\text { Technical } \\
\text { Malfunctioning }\end{array}$ & Equipment & $\begin{array}{l}\text { Frequency } \\
\text { Recency } \\
\text { Impact }\end{array}$ & $150(15 \%)$ & $\begin{array}{l}0.2 \\
0.9 \\
1.8\end{array}$ & $\begin{array}{l}0.5 \\
0.9 \\
1.0\end{array}$ \\
\hline \multirow[t]{2}{*}{$\begin{array}{l}\text { Vehicle Design } \\
\text { and Space }\end{array}$} & Crowding & $\begin{array}{l}\text { Frequency } \\
\text { Recency } \\
\text { Impact }\end{array}$ & $929(93 \%)$ & $\begin{array}{l}2.0 \\
1.6 \\
1.2\end{array}$ & $\begin{array}{l}0.9 \\
1.2 \\
0.9\end{array}$ \\
\hline & Discomfort & $\begin{array}{l}\text { Frequency } \\
\text { Recency } \\
\text { Impact }\end{array}$ & $738(74 \%)$ & $\begin{array}{l}1.1 \\
1.0 \\
1.6\end{array}$ & $\begin{array}{l}0.9 \\
1.0 \\
0.8\end{array}$ \\
\hline \multirow[t]{2}{*}{ Traffic Planning } & Fare structure & $\begin{array}{l}\text { Frequency } \\
\text { Recency } \\
\text { Impact }\end{array}$ & $592(59 \%)$ & $\begin{array}{l}1.2 \\
1.5 \\
1.7\end{array}$ & $\begin{array}{l}1.1 \\
1.2 \\
0.9\end{array}$ \\
\hline & Scheduling & $\begin{array}{l}\text { Frequency } \\
\text { Recency } \\
\text { Impact }\end{array}$ & $751(75 \%)$ & $\begin{array}{l}1.3 \\
1.1 \\
2.2\end{array}$ & $\begin{array}{l}0.9 \\
1.1 \\
0.8\end{array}$ \\
\hline Other & Bus stop & $\begin{array}{l}\text { Frequency } \\
\text { Recency } \\
\text { Impact }\end{array}$ & $717(72 \%)$ & $\begin{array}{l}1.1 \\
1.0 \\
1.7\end{array}$ & $\begin{array}{l}0.9 \\
1.1 \\
0.8\end{array}$ \\
\hline
\end{tabular}

Note: Frequency of experience-a similar incident was rated on the scale Never (0), $A$ few' times (1),Occasionally (2), or Regularly (3); Recency of experience-rated on the scale Do not remember, or Further back (0), Some time the last year (1). Last month (2), or Last week (3); Degree of negative impact-rated on the scale Not at all negative (0). Somewhat negative (1). Rather much negative (2), or Very negative (3). 


\begin{tabular}{|c|c|c|}
\hline \multicolumn{3}{|c|}{$\begin{array}{c}\text { Table 4 } \\
\text { Average Rated Frequencies of Incidents } \\
\text { in Each Superordinate Group }\end{array}$} \\
\hline Superordinate Group & Question & $M$ \\
\hline Treatment and Action & $\begin{array}{l}\text { Frequency of experience } \\
\text { Recency of experience } \\
\text { Degree of negative impact }\end{array}$ & $\begin{array}{l}0.5 \\
0.8 \\
2.4\end{array}$ \\
\hline Punctuality & $\begin{array}{l}\text { Frequency of experience } \\
\text { Recency of experience } \\
\text { Degree of negative impact }\end{array}$ & $\begin{array}{l}1.1 \\
1.0 \\
2.1\end{array}$ \\
\hline Information & $\begin{array}{l}\text { Frequency of experience } \\
\text { Recency of experience } \\
\text { Degree of negative impact }\end{array}$ & $\begin{array}{l}0.5 \\
0.8 \\
2.2\end{array}$ \\
\hline Technical Malfunctioning & $\begin{array}{l}\text { Frequency of experience } \\
\text { Recency of experience } \\
\text { Degree of negative impact }\end{array}$ & $\begin{array}{l}0.2 \\
0.9 \\
1.8\end{array}$ \\
\hline Vehicle Design and Space & $\begin{array}{l}\text { Frequency of experience } \\
\text { Recency of experience } \\
\text { Degree of negative impact }\end{array}$ & $\begin{array}{l}1.6 \\
1.3 \\
1.4\end{array}$ \\
\hline Traffic Planning & $\begin{array}{l}\text { Frequency of experience } \\
\text { Recency of experience } \\
\text { Degree of negative impact }\end{array}$ & $\begin{array}{l}1.3 \\
1.3 \\
2.0\end{array}$ \\
\hline Other (bus stop) & $\begin{array}{l}\text { Frequency of experience } \\
\text { Recency of experience } \\
\text { Degree of negative impact }\end{array}$ & $\begin{array}{l}1.1 \\
1.0 \\
1.7\end{array}$ \\
\hline
\end{tabular}

group would correspond to the numbers of complaints (Table 1) or recalled NCIs in the interviews (Table 2), Table 4 shows that NCIs concerning punctuality are among the most frequently experienced, as the results of the preceding studies suggested. However, NCIs related to Treatment and Action are less frequently experienced whereas incidents related to Vehicle Design and Space are more frequently experienced. 


\section{Discussion}

The present results were fairly consistent across three different CIT techniques that may be employed in research on perceived service quality (PSQ) attributes of public transport. Two of the techniques (content analysis of complaints and on-board interviews) are conventional, whereas the third survey-type of technique, to the best of our knowledge, has not been used before in this way to obtain data on critical incidents. Apparently, stronger inferences are possible to make, given that these three complementary techniques demonstrate communality of results.

The main categories in Tables 1, 2 and 3 were used to analyze if attributes identified in previous PSQ research (see Edvardsson 1996) generalize to public transport service. The results from all three techniques seem to warrant the conclusion that PSQ attributes of public transport services involves employee behavior, reliability, and simplicity, as has been found in other service areas (e.g., restaurants, hotels, and banks). A majority of the complaints and negative critical incidents were related to employee behavior (Treatment and Action) and reliability of the service (Punctuality). In particular, the complaints were also frequently concerned with insufficient information (Information). The survey results partly confirmed these findings but also suggested that the design of and space available in vehicles are important.

Consistent with previous findings (e.g., Berry and Parasuraman 1992; Bitner, Booms and Tetreault 1990; Edvardsson 1996; Zeithml, Parasuraman, and Berry 1990), PSQ attributes of public transport services referred to how employees treat the customers. In public transport, the driver is the employee to whom the customer is most frequently exposed. Accordingly, many NCIs were related to driver behavior. These critical incidents may be very important for the customer's overall evaluation of the service. The complaints and interview data suggest that drivers arouse feelings of frustration and sometimes even aggression. For instance, several NCIs attested to the anger some travelers felt when the driver refused to listen or simply ignored them. NCIs related to interaction with other staff did not seem to have the same intensity. It is also natural that the driver 
becomes the target for many complaints that customers may have, for which the driver is not responsible. The driver is furthermore very important since he or she is directly responsible for the passenger's safety and security.

Several studies (Bitner 1990; Grönroos 1990; Zeithaml, Parasuraman, and Berry 1990) have demonstrated that PSQ attributes include reliability and trust. Punctuality is known to be a salient aspect of reliability in public transportation (Borjesson and Kjellgren 1993; Bradley et al. 1989). When the bus departs early or late, or when no bus arrives at all, the travelers are obviously annoyed. If this occurs frequently, customers will eventually loose trust in the service. Critical incidents related to punctuality or reliability sometimes appeared to be due to weather conditions or rush hour. Still, the public transport company was blamed because staff were expected to be responsible for managing such situations. In fact, the company's traffic planning was not perceived to be efficient. For instance, a frequent complaint concerned a lack of coordination of connections.

Furthermore, PSQ attributes have been found to also include simplicity (e.g., information and opening hours) (Edvardsson 1996; Grönroos 1990). As the present complaint data suggested, problems with incomplete or confusing information were prevalent. Complaints concerned missing or difficult-to-access information about times (delays, travel time), destinations, and tickets. It is clearly important for the traveler to know these things. However, frequently they were unable to access relevant information from the driver. Even though this may reflect that drivers act inappropriately, it may also be the case that the means of conveying the information need to be redesigned.

Inconsistent with the hypothesis, no reported incidents were related to recovery when something goes wrong (Albrecht and Zemke 1985; Johnston 1995). Since the three techniques that were used reveal only negative episodes, recovery may still be important, but, in this respect, customers are satisfied with the performance of the public transport company.

In summary, the main sources of NCls were employee behavior and reliability. Also, simplicity was identified as a source of negative critical incidents. This suggests that PSQ attributes of public transport are similar to findings in 
other service areas. Contrary to the hypothesis, vehicle design and space were noted as a cause of negative critical incidents. Furthermore, recovery may not be a PSQ attribute. Thus, inferences made from complaints and negative critical incidents can provide managers with useful information about perceived service quality attributes.

A question that future research should address is whether the PSQ attributes of public transport identified in the present study are exhaustive. As alluded to, it is possible that data on negative critical incidents do not inform about PSQ attributes that play no role for experiencing the service as dissatisfying. Another related question that should be addressed in future research (see Johnston 1995) is the relationship between negative critical incidents, perceived service quality, and satisfaction/dissatisfaction. Although additional research is needed, a clear implication of the current research is that it highlights the important role of employee behavior. This is not frequently realized by public transport companies and motivates more extensive training of employees.

\section{Appendix}

\section{Prototypical incidents included in the mail-survey questionnaire}

Driver refused to listen. You get to the bus/streetcar and let the machine punch your ticket/register your smartcard, which the driver then asks to check. He informs you that the ticket/card is not valid without explaining why. You have to buy a new ticket. A later investigation shows that the ticket/card was, in fact, valid.

Not permitted to embark the vehicle. You are taking a trip which involves getting a connecting bus/streetcar. Both the vehicle you are on and the connecting one arrive simultaneously at the station. Together with several other passengers you get off and run to the connecting bus/streetcar, but the driver closes the doors and drives away. It is not past the listed departure time, and it would not have taken more than 30 seconds for the driver to let you on.

Careless driving. The vehicle is traveling at high speed. Every so often the driver brakes abruptly. Before you want to get off you press the stop button. The 
driver appears not to have noticed and is about to pass your stop. At the last minute he become aware of the signal and brakes abruptly.

Not permitted to get off the vehicle. Just as you are about to get off the bus/ streetcar, the doors suddenly close and the bus takes off before you have a chance to leave. You push on the door but to no avail. Several passengers, including you, shout at the driver to stop. He does not respond and you are forced to stay on until the next stop.

Driver did not stop at the bus stop. You are waiting at the bus stop/streetcar stop where you are clearly visible. You see the half-full vehicle approaching and believe that you have eye contact with the driver. You take a step forward and prepare to get on, but the driver does not stop.

Bad treatment from other staff. You call the public transport company to inquire about a specific bus/streetcar schedule. It takes several minutes before you get an answer, and when you finally do get a response, the information is given in a very unfriendly manner.

Early departure. You decide to take a bus/streetcar and arrive at the stop in plenty of time only to discover that the vehicle has already left well before the scheduled time.

Late departure. You decide to take a bus/streetcar and you get to the stop in plenty of time. You wait for the vehicle to arrive, and when it finally does, it is very late.

Canceled trip without notice. You join other people in good time at the stop. After a long wait, there is still no sign of the bus/streetcar, and you soon realize that none is going to come. You are forced to either wait for the next one or find some other way of reaching your destination.

Delayed departure time. You have checked the timetable for a suitable departure time and wait for the bus/streetcar. At the scheduled time, there is no vehicle in sight. After a while, it turns up, but you get no explanation as to why it was late.

Incorrect display. While you wait at the stop, a bus/streetcar for a destination other than the one you want arrives, stops, and then continues. When it has 
left and no other bus is in sight, you and other passengers begin to suspect that, in fact, that must have been the vehicle you were waiting for. On checking the timetable, you discover that no bus/streetcar going in the direction shown on the vehicle was due to depart from that stop at that time. Thus, the incorrect destination had been displayed. You must now either wait for the next one or find some other means of reaching your destination.

Tickets and their validity. You have already checked the ticket price with the public transport company. When you get on the bus/streetcar, you pay that price. That morning, a ticket inspection is carried out. You are not concerned, but the inspector insists that you have not paid the correct price. You question this, as you know you have paid the quoted fare.

Equipment. You start to suspect that the ticket machine on your bus/streetcar does not always register your smartcard correctly. This means that, in the event of an inspection, you cannot prove that you have paid the correct fare.

Crowding. The arriving vehicle is almost full. The driver stops and allows you and several other passengers onboard. Some of the new passengers find a place to sit, but others, including you, are forced to stand up for the whole trip. During the remainder of the trip, even more passengers are allowed onboard.

Comfort. You get on a bus/streetcar. After a while, you notice how warm/ cold it is in the vehicle. The heating is turned on full/is turned down. The temperature is unpleasant.

Fare structure. You begin to compare the price you pay to what you consider to be a reasonable price - that is, you compare the price you pay to use the public transport system with the service you believe is actually provided.

Scheduling. In order to arrive at your destination, you are required to change buses/streetcars, but the connecting vehicle has already left. This means a long wait for you until the next bus/streetcar departs.

Bus stop. The bus stop/streetcar stop you are waiting at has no shelter/is in a bad condition. 


\section{Notes}

'In previous studies using the CIT (e.g., Edvardsson 1992, Bejou, Edvardsson, and Rakowski 1996), it has been found to be sufficient to analyze between 200 and 300 critical incidents.

${ }^{2}$ One of them also classified the complaints.

${ }^{3}$ Data are reported only for those questions that are directly relevant to the present aim.

${ }^{4}$ Confirming that few complain to the public transport company, only 22 percent stated in the questionnaire that they had ever filed a complaint. More NCIs were remembered by those who had filed complaints than those who had not although the difference did not reach statistical significance $(M=14.1$ vs. 9.4, $\mathrm{p}>0.05$ ).

\section{References}

Albrecht, C., and R. Zemke. 1985. Service America. IL: Dow Jones-Irwin.

Anderson, B., and S. Nilsson. 1964. Studies in the reliability and validity of the critical incident technique. Journal of Applied Psychology 48: 398-403.

Andreassen, W. T. 1995. (Dis)satisfaction with public services: The case of public transportation. Journal of Services Marketing 9:30-41.

Bejou, D., B. Edvardsson, and J. P. Rakowski. 1996. A critical incident approach to examining the effects of service failures on customer relationships: The case of Swedish and U.S. airlines. Journal of Travel Research 1:35-40.

Benister, D. 1992. Demographic structures and social behavior. In Transport Growth in Question, 12th International Symposium on Theory and Practice in Transport Economics, 109-149. Paris: European Conference of Ministers of Transport, OECD.

Berry, L. L., and A. Parasuraman. 1992. Prescriptions for a service quality revolution in America. Organizational Dynamics 20: 5-15.

Bitner, M. J., B. H. Booms, and M. S. Tetreault. 1990. The service encounter: Diagnosing favorable and unfavorable incidents. Journal of Marketing 54 (Jan.): 71-84.

Bitner, M. J. 1990. Evaluating service encounters: The effect of physical surroundings and employee responses. Joumal of Marketing 54 (April): 69-82. 
Bradley, M., E. Kroes., S. Widlert., R. Sheldon., T. Gärling, and S. Uhlin. 1989. Preferences for bus underground services in Stockholm. Paper presented at the Fifth World Conference on Transport Research, July 10-14, Japan: Yokohama.

Börjesson, M., and A. Kjellgren. 1993. Framsteg for kollektivtrafiken. Redovising av TFBs/KFBs forsknings-, utvecklings- och demonstrationsprojeckt om kollektivtrafik [Summaries of results from projects sponsored by Swedish Transport and Communications Research Board]. Stockholm: Kommunikationsforskningsberedningen (KFB).

Cadotte, E. R., and N. Turgeon. 1988. Dissatisfiers and satisfiers: Suggestions for consumer complaints and compliments. Journal of Consumer Satisfaction, Dissatisfaction and Complaining Behavior 1: 74-79.

Day, R. L., K. Grabicke, T. Schaetzle, and F. Staubach. 1981. The hidden agenda of consumer complaining. Journal of Retailing 57 (Fall): 86-106.

Edvardsson, B. 1988. Service quality in customer relationships: A study of critical incidents in mechanical engineering companies. The Service Industries Journal 8: 427-443.

Edvardsson, B. 1992. Service breakdowns: A study of critical incidents in an airline. International Journal of Service Industry Management 3:17-29.

Edvardsson, B. 1996. Tjansteutveckling med inbyggd kvalitet [Service development with in-built quality]. Karlstad: Service Research Center.

Everett, P. B., and B. G. Watson. 1987. Psychological contributions to transportation. Handbook of Environmental Psychology 2:987-1007.

Flanagan, J. C. 1954. The critical incident technique. Psychological Bulletin 51: $327-$ 357.

Folkes, V. S. 1994. How customers predict service quality. What do they expect? In Service quality: New directions in theory and practice, ed. R. T. Rust and R. L. Oliver. California: Sage.

Grönroos, C. 1990. Service management and marketing: Managing the moments of truth in service competition. New York: Lexington Books.

Hartgen, D. T. 1981. Transportation and the behavioral sciences. In Human behavior and environment: Advances in theory and research, ed. I. Altman and J. F. Wohlwill. New York: Plenum.

Johnston, R. 1995. The determinants of service quality: Satisfiers and dissatisfiers. International Journal of Service Industry Management 6: 53-71. 
Johns, N., and P. Tyas. 1997. Customer perceptions of service operations: Gestalt, incident or mythology? The Service Industries Journal 17: 474-488.

Lovelock, C. H. 1983. Classifying services to gain strategic marketing insights. Journal of Marketing 47 (summer): 9-20.

Olsen, Morten J. 1992. Kvalitet $i$ banktjanster-Privatkunders upplevda problem med banktjanster [Quality in banking services-problems in banking services experienced by private customers]. Karlstad: Service Research Center.

Ronan, W. W., and G. P. Lantham. 1974. The reliability and validity of the critical incident technique: A closer look. Studies in Personnel Psychology 6: 53-64.

Stauss, B. 1992. Attribute-based versus incident-based measurement of service quality: Results of an empirical study in the German car service industry. In Quality management in services, ed. P. Kunst and J. Lemmink. Maastricht: Van Gorcum.

Stauss, B. 1993. Using the critical incident technique in measuring and managing service quality. In The Service Quality Handbook, ed. E. E. Scheuing and W. Christopher. New York: American Marketing Association.

Strandvik, T. 1994. Tolerance zones in perceived service quality. Helsinki: Swedish School of Economics and Business Administration.

Youngdahl, W., and D. Kellog. 1996. The relationship between service customer's quality assurance behaviors, satisfaction, and effort: A cost quality perspective. Journal of Operation Management 15: 19-32.

Zeithaml, V., A. Parasuraman, and B. Berry. 1990. Delivering quality service-balancing customer perceptions and expectations. New York: The Free Press.

\section{Acknowledgment}

This research was financially supported by a grant to the Service Research Center from the Swedish Communications and Transport Research Board.

\section{About the Authors}

Margareta Friman is a postgraduate student in psychology at Göteborg University and a researcher at the Service Research Center at the University of Karlstad. Her research focus is on perceived service quality and customer satisfaction in public transport services. 
Bo Edvardsson is a Professor of Business Management and the Director of a Service Research Center at the University of Karlstad. His research interest is in the field of service quality, with an emphasis on service design and development of new services.

Tоммy GärLING is a professor of psychology in the Department of Psychology at Göteborg University. His main research interest is decisionmaking and judgement, including applications in travel behavior. 